\title{
Peertechz
}

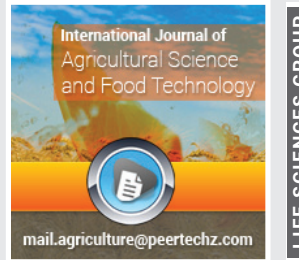

\section{Market chain analysis of Teff in Tole Woreda, Ethiopia}

\section{Tariku Legese Dibaba*}

Department of Agricultural Economics, College of Agriculture, Oda Bultum University, Ethiopia
Received: 05 November, 2020

Accepted: 21 January, 2021

Published: 22 January, 2021

*Corresponding author: Tariku Legese Dibaba, Department of Agricultural Economics, College of Agriculture, Oda Bultum University, Ethiopia, Tel: +251912282198; E-mail: obseeabdii12@gmail.com

Keywords: Market chain analysis; Multivariate probit; OLS; Outlet choice; Tole; SCP; Teff

https://www.peertechz.com

\section{Check for updates}

\section{Abstract}

Teff accounts for the largest share of the cultivated area and the major cash crops grown mainly for market in the study area. But the nature of the product and lack of proper functioning marketing system often resulted in lower producers' price. The current research attempted to analyze the market chain of teff in Tole woreda Oromia Region of Ethiopia with specific objective of assessing the structure-conduct- performance paradigm of teff, identifying major factors influencing market outlet choice of teff producing farmers and to determine factors affecting amount of market supply of teff by farm households in Tole woreda. Data for the study were collected from both primary and secondary sources. The primary data were generated from farmers and traders survey. A total of 122 teff producing sample households from four teff producing kebeles of the woreda and 42 teff traders from six teff marketing town were surveyed. Both descriptive and econometrics analyses were conducted. The structure-conduct-performance approach was used to evaluate teff market performance. The Market concentration ratio of largest four firms at the woreda level was $59.44 \%$ which indicated oligopolistic market structure. The econometric model results indicated that the amount of teff supply to market was significantly affected by age, educational status, total land holding, amount of credit used for teff production, number of oxen owned by household, lag market price of teff and Distance from home to all weather road at 1,5,10\% significance level. The multivariate probit model results indicated that age, sex, educational status, frequency of extension contact, off-farm activities, total land allocated for teff, access to information and family size s significantly influenced teff producer's choice of market outlets for their produce. Thus, the government and concerned stockholders should expand equal accessibility of infrastructures such as road and transportation facilities to reducing transaction to promote the effective marketing of teff product supply through all outlets.

\section{Introduction}

\section{Background of the study}

Ethiopia produces more cereal crops than other agricultural products with Cereals account for more than $60 \%$ of rural employment, $81 \%$ of total cultivated land, more than $42 \%$ of atypical household's food expenditure and more than $60 \%$ of total calorie intake [1]. Out of the total grain crop area in the country, $81.27 \%$ (10.22million ha) was under cereals. Cereals Teff is the first In Ethiopia area coverage and production. The scientific name of teff is Eragrostisteff (Zucc.) (Vavilov, 1951). In oromia regional state, the land allocated for the production of teff in the year 2017 was 1,441,029.78ha. Moreover, the regional production of teff in the year 2017 was $24,737,963.79$ quintal with the productivity of $17.17 q u / h a$ which is greater than the productivity of the country $16.64 \mathrm{qu} / \mathrm{ha}$ [2].

Teff is the highest-priced cereal grown in the country due to long marketing chain with little or no value addition. The National teff Strategy has been prepared following a value chain approach, which includes coordination of all steps in the chain, adding value at each stage, and a marketing approach to address local, national, and international consumer demand [3].

Ethiopian agriculture sector continues to face a number of problems and challenges until now. The major ones are absence of well-functioning markets and adverse climatic conditions need mention [4]. The nature of the product and lack of proper functioning marketing system often resulted in lower producers' price. According to Efa, et al. [5] poor market linkages, collusion of buyers on price setting, high transport cost and access to nearest market are the major marketing problem.

Some research conducted on marketing participation of smallholder farmers in different teff producing areas. Mohammad (2011) and Azeb [6] conducted a study on market chain of teff, wheat and analyses of the teff market participation of farm households respectively. But they fail to study the farmer's market outlet choice of teff and no such 
previous studies have been conducted in Tole woreda. This study therefore, has attempted to contribute in filling the information gap by identifying factors affecting teff market supply and market choice outlet of farmers in Tole woreda.

\section{Research methodology}

Description of the study area: Tole Woreda is located in South west from capital city Addis Ababa and East from the administrative town, Woliso. Bantu is the Worde administrative town since 1936 and it is located at $85 \mathrm{~km}$ to the south west of Addis Ababa and $80 \mathrm{~km}$ to the East from the zonal administrative town Woliso. The woreda has 24 kebeles ( 22 rural and 2 urban kebeles). Tole woreda is located between $8^{\circ} 28^{\prime \prime} \mathrm{N}-8^{\circ} 47^{\prime \prime} \mathrm{N}$ and $38^{\circ} 17^{\prime \prime} 1 / 2 \mathrm{E}-38^{\circ} 29^{\prime \prime} \mathrm{E}$ and its total area is 41,019 hectares which is only $6 \%$ of the zonal area. It is bordered on the southwest by Kokir, on the west by Bacho, on the northwest by Elu, on the northeast by the Awash River which separates it from Sebeta hawas, and on the east and south by Kersana Kondaltiti. The Population projection values of 2017 population census report, the total population of Tole woreda is 80,199 , of whom 40,551 were men and 39,648 were women, 4,202 of its population were urban dwellers. The elevation of the area ranges between 2100 - 3080 masl (OWUDB, 2017). Tole woreda has only Dega (temperate climate) and Woina Dega (sub-tropical climate) agro climatic zone, which accounts $20 \%$ and $80 \%$ respectively. It experiences average temperature between $18^{\circ} \mathrm{C}$ and $20^{\circ} \mathrm{C}$ and annual rainfall varies between 1600 and $2000 \mathrm{~mm}$.

Climate: Tole woreda has good climatic conditions and this is an opportunity for cereal crops. The elevation of the area ranges between 2100- 3080 masl (OWUDB, 2017). Tole woreda has only Dega (temperate climate) and Woina Dega (subtropical climate) agro climatic zone, which accounts $20 \%$ and $80 \%$ respectively. It experiences average temperature between 18 and $20^{\circ} \mathrm{C}$ annual rainfall varies between 1600 and $2000 \mathrm{~mm}$ the main rainfall starts in June and ends in September. In the woreda Vertisols (Black basalthic soils), Nitosols (Red basaltic soils) and Cambisol (Shallow and sandy soils with coarse texture) type of soils are mainly identified (OWUDB, 2017).

Land use: Tole Woreda has various land use types that could be classified into arable land, irrigated land, grazing land, common land, land covered by water, land used for social service and forest land. The woreda has a total area of 41,019 ha of which $28,843.74$ ha arable land, 348ha forest land, 212.68ha covered by water, 572.44ha common land, 437.93ha land used for social service and 1776.4ha grazing land [6].

The farming system is characterized by mixed croplivestock farming. Farmers produce different crop enterprises in the rain-fed farming in order to secure their family food supply and also cover various household expenses. The major crops grown in the woreda include Teff, wheat, barley, rough pea and maize. Teff and wheat are the major sources of daily food of the population [6] Figure 1.

\section{Data types, sources and methods of data collection}

Qualitative and quantitative data were estimated to get the overall picture of teff producers and traders in the study area.

\section{Sources of data}

Primary and secondary sources of data were used. Primary data sources were smallholder farmers randomly selected from different rural kebeles, and traders at different levels ranging from farmer traders to regional level wholesales. The source of secondary data list of different and relevant published and unpublished reports as well as bulletins from CSA.

\section{Sampling technique and sample size}

Sampling techniques: In this study a multi stage sampling procedure was used to select the rural kebeles and sample households. Tole woreda was purposively selected based on its potential production of teff from the SW Shewa zone. In the first stage, Tole woreda kebeles were stratified into producer and non-producer of teff. Since three kebeles were town kebeles they are not produce teff and three kebeles were found in Dega agro climate almost all of them participated in producing barley and inset rather than teff. Totally Out of the 24 kebeles in Tole woreda and 5 kebeles did not produce teff whereas 19 kebeles were teff producer. In the second stage 19 teff producer kebele is purposively selected. From these teff producing kebeles 4 kebele were selected randomly. Since the population and area of production were homogeneous to producer the selected kebele was almost representative to the woreda. In the third stage, sample respondents households was randomly taken from each selected kebeles probability proportional to the size of their sample teff producer distribution. The study was also target to trader of the teff in the study area. The sites for the trader were towns market in which a better sample of teff traders existed. On the basis of flow of teff, 6 markets (kusaye, Habebe, Bantu, Asigor, Sebeta and Alemgena) were selected. The sample size determination was employed using the formula given by Yamane [7].

$$
\mathrm{n}=\frac{N}{1+N(e)^{2}}=\frac{13572}{1+13572(0.09)^{2}}=122
$$

Where: $\mathrm{n}=$ the sample size needed.

$\mathrm{N}=$ the total number of teff producer households in the woreda which were 13572 .

$\mathrm{e}=$ margin of error and for this study $9 \%$ was be used to obtain manageable sample size.

Generally, from 6 regional wholesalers, 27 farmer traders, 14 urban wholesalers 4 regional retailers, 18 urban retailers $4,17,7,3$, and 9 were selected randomly based on probability proportional to size in the selected market. In addition, 2 commission men were randomly taken which make the total 42 participants.

\section{Methods of data collection}

Primary data was collected using semi-structured questionnaires from teff traders and teff producers and interview from key informative. The key informant was done by interviewing in-personal the people like leaders of each of the kebele, DAs and woreda trade, industry and urban development. 


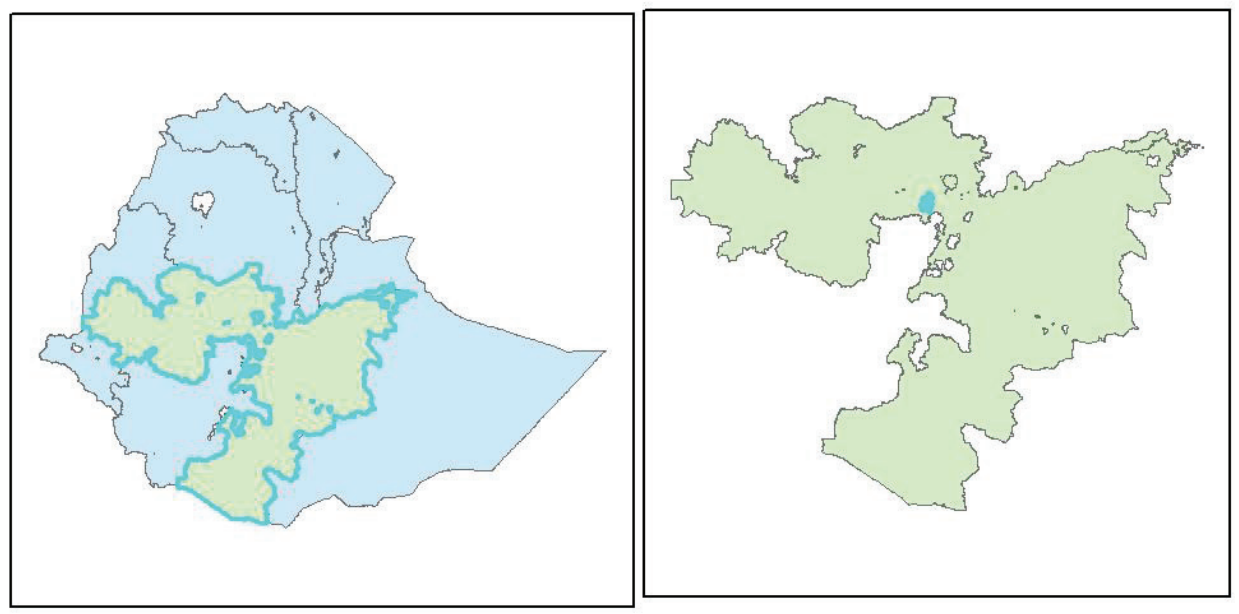

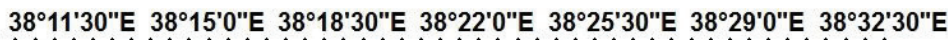

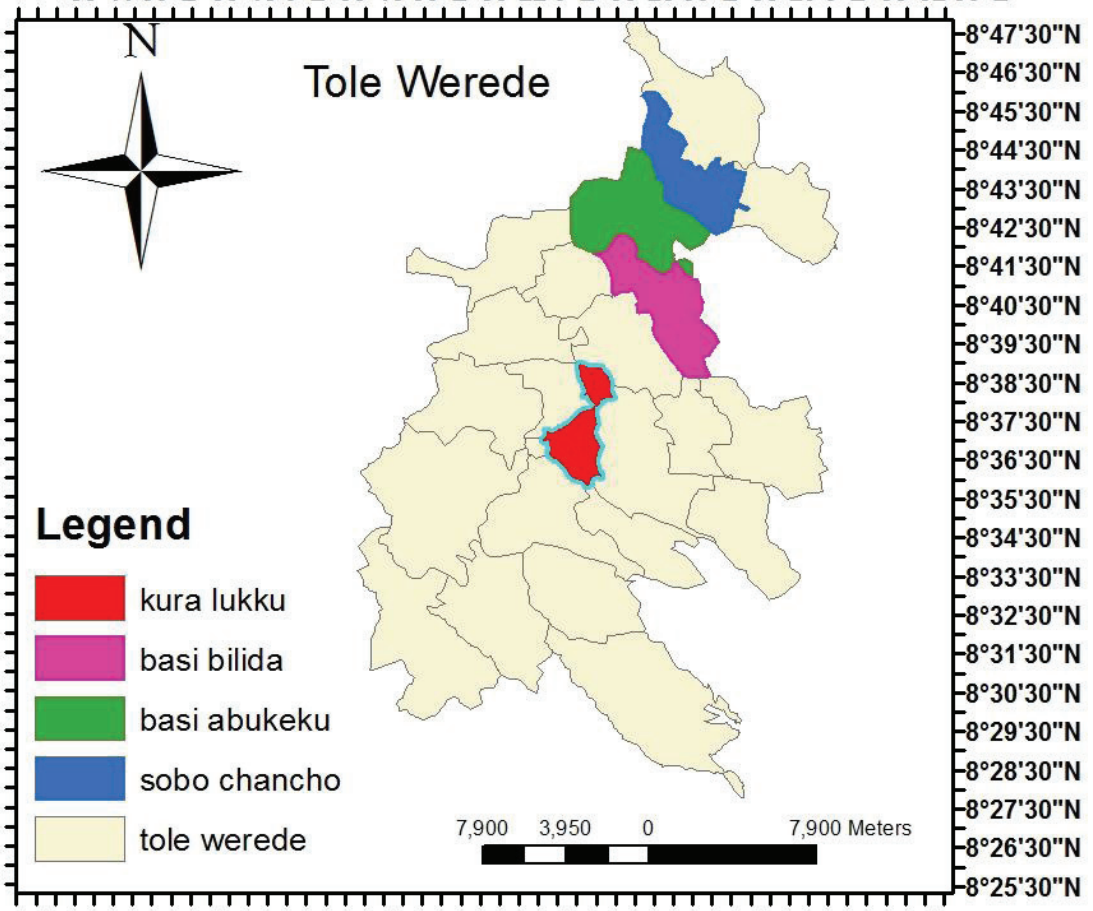

Figure 1: Map of the study woreda.

\section{Methods of data analysis}

For these study two types of data analysis, namely descriptive statistics for qualitative data and econometric analysis for quantitative data were used for data analysis.

\section{Descriptive statistics}

Descriptive statistics such as mean, standard deviation and percentage have been used in the process of examining and describing household characteristics, marketing functions and trader characteristics.

\section{Structure conduct performance (S-C-P) model}

This approach was developed in the United States as a tool to analyze the market organization of the industrial sector and then it was applied to assess the agricultural marketing system [8]. The model examines the fundamental relationships between market structure, conduct and performance.

The producers' share is the commonly employed ratio calculated mathematically as, the ratio of producers' price (exvessel) to consumers' price (retail). Mathematically, producers' share can be expressed as:

$$
\mathrm{PS}=\frac{P x}{P r}=1-\frac{\mathrm{MM}}{P r}
$$

Where: PS = Producers' share Px $=$ Producers price of teff

$\operatorname{Pr}=$ Retail price of teff which is consumer price $M M=$ marketing margin 
Total Gross Marketing Margin (TGMM) is always related to the final price paid by the end buyer and is expressed as percentage [9].

$$
\text { TGMM }=\frac{\text { end buyer price-first seller price }}{\text { end buyer }(\text { consumer }) \text { price }} \times 100
$$

The TGMM is useful to calculate producer's gross marketing margin (GMMp) which is the portion of the price paid by the consumer that goes to the producer. The producer's margin is calculated as:

$$
\text { GMMp }=\frac{\text { end buyer price-total growth marketing margin }}{\text { end buyer price }} \times 100
$$

$$
\mathrm{NMM}=\frac{\text { TGMM-marketing cost }}{\text { producers price }} \mathrm{X} 100
$$

Where: $\mathrm{NMM}=$ Net Marketing Margin

To find the benefit share of each actor the same concept was applied with some adjustments. In analyzing margins then, marketing margin at a given stage (GMM) was computed as

$$
\mathrm{GMM}=\frac{\text { selling price }- \text { buying price }}{\text { consumer price }} X 100
$$

\section{Econometric analysis}

Econometric model for the amount of teff market supply : Different models can be employed to analyze the determinants of market supply. The commonly used ones are multiple linear regression, Tobit and Heckman's sample selection models. in the study area all teff producers participate in the market by supplying their produce and therefore there is no clustering of teff producers in teff market participant and non-participant. Thus, for this study, multiple linear regression models was used to identify determinants of teff marketed supply. In matrix form was specified as:

$$
\mathrm{Y}=\beta \mathrm{X}+\mathrm{Ui}
$$

Where $\mathrm{Y}=$ Total teff supplied to the market

$\beta=a$ vector of estimated coefficient of the explanatory variables

$$
\begin{aligned}
& \mathrm{X}=\text { vector of explanatory variables } \\
& \mathrm{Ui}=\text { disturbance term }
\end{aligned}
$$

\section{Determinants of market outlet choice}

Multivariate probit model (MVP) was applied for household variation in the choice of a market outlet and to estimate several correlated binary outcomes jointly. The market outlets had been categorized into four groups: wholesaler, farmer traders, retailers and consumer market outlets. Each farmer can use one or more marketing outlets or several combinations of different outlets which maximize the expected utility and due to this there was some overlapping and many farmers sell on more than one market outlet.

\section{Results and discussion}

\section{Demographics and socioeconomics characteristics of households}

In this study, based on the result of the survey, both male headed household and female headed household participated in production of teff (Table 1). The survey result showed the total sampled population of teff producers was $81.1 \%$ of male-headed household and 18.9 $\%$ of female-headed indicating that male headed households dominate teff production as expected.

The educational background of the sample household heads was believed to be an important role adoption of new yield enhancing technology and crop pattern. Further, it was assumed that household head with good education level and had better understanding about the prevailing market scenario. About $41.8 \%$ household heads were illiterate. However, $15.6 \%$, $26.2 \%, 13.1 \%$ and $3.3 \%$ had basic education, primary, secondary school and higher education respectively Table 2 .

\begin{tabular}{|c|c|c|c|}
\hline Market & Traders & Number of traders & No. traders selected \\
\hline Kusaye & Farmer trader & 10 & 7 \\
\hline Habebe & Farmer trader & 12 & 8 \\
\hline \multirow{3}{*}{ Bantu } & Farmer traders & 5 & 2 \\
\hline & R. wholesalers & 6 & 4 \\
\hline & R. retailers & 4 & 3 \\
\hline \multirow{2}{*}{ Asgori } & Wholesalers & 8 & 4 \\
\hline & Retailers & 4 & 2 \\
\hline \multirow{2}{*}{ Sebata } & Wholesalers & 4 & 2 \\
\hline & Retailers & 6 & 3 \\
\hline \multirow{2}{*}{ Alemgena } & Wholesalers & 2 & 1 \\
\hline & Retailers & 8 & 4 \\
\hline \multicolumn{2}{|r|}{ Total } & 69 & 40 \\
\hline
\end{tabular}

The survey on this major demographic factor, measured in years, provided a clue on working ages of households. The average household head's age was 42.93, which ranges between 22 and 82 years, where largest proportions of the household head was within the productive age (amid of 15

Table 1: Sample distribution of teff traders.

Table 2: Sex and educational status of teff producing households.

\begin{tabular}{|c|c|c|}
\hline Variables & Total household & $\%$ \\
\hline Sex & & \\
Male & 99 & 81.1 \\
Female & 23 & 18.9 \\
\hline Education & & \\
Illiterate & 51 & 41.8 \\
Basic education & 19 & 15.6 \\
Primary education & 32 & 13.2 \\
\hline Secondary education & 16 & 3.3 \\
\hline Higher education & 4 & 58.2 \\
\hline Access to extension service & & 41.8 \\
\hline Yes & 71 & \\
No & 51 & 31.1 \\
\hline Access to credit & & 68.9 \\
\hline Yes & 38 & 84.4 \\
\hline No & 84 & \\
\hline Access to information & 103 & \\
\hline Source: Own survey result (2018) & & \\
\hline
\end{tabular}


and 64 years). A family size was ranging between (1-11) was observed in the sampled farming households; the available data indicated that average family size in each household was $\mathbf{5 . 8 2}$. Availability and adequacy of road was important prerequisite to link producers with markets in reduced transaction costs. The assessments on this continuum, measured in kilometer where most households could access the entry within $3.54 \mathrm{~km}$ on average was approximately one hour of normal walk.

\section{Teff marketing channels}

The analysis of marketing channel intended to provide a systematic knowledge of the flow of the goods and services from its origin of production to the final destination of ultimate consumers. The survey result of sampled respondents depicts, out of 4442.5 quintals of teff produced, 2262 quintals $50.32 \%$ of teff marketed. Even though the teff channel in Tole woreda was complicated, the major channels of teff identified during the survey were explained as follows Figure 2:

\section{Analysis of structure, conduct and performance of teff}

Structure of the teff market: The structure of the teff market is characterized using indicators such as, market concentration, the degree of transparency (market information) and entry conditions.

Degree of market concentration: The analysis of the degree of market concentration was carried in Bantu markets, where regional wholesales, Regional retailer and farmer trader of the commodities were significantly involved. The result of sample market teff traders' concentration ratio was found to be $59.44 \%$. The result showed that, the teff market concentration ratio in the study area illustrated the presence of strong oligopoly market structure.

Barrier to entry and exit: With the presence of very high barriers to entry, established firms are difficult to stay longer in business. In this study educational background of the traders and lacks of working capital were used to analyze barriers of teff market entry and exit.
Level of education: The trader's survey result showed that, about $5.3 \%$ of the respondents were illiterate; while the remaining $39.5,44.7$ and $10.5 \%$ of traders have attended formal school with the level of primary, secondary and basic education respectively. The majority of the traders were entitled to formal educations which confirmed that trader's educational background seem to be a barrier to entry into teff trade.

Lack of working capital: Working capital refers to the amount of money required by teff traders to enter into the trading business. According to the survey result, about $71.1 \%$ of the sample traders identified that lack of capital was one of the major entry barriers to enter in to teff trading. $18.4 \%$ also reported that the combination of capital shortage and some government policy on tax were major barriers to enter teff trading.

Market: There were no agreement upon procedures for analyzing the elements of market conduct. In this study conduct of teff market was analyzed in terms of the trader's price setting, purchasing and selling strategies.

\section{Producers' market}

The date from Tole Industry and Urban development Office pointed out that, supply of teff occurs mainly from half of November to end February. But the supply started declining in the year from May to September. It is also reported that, all farmers supply their teff produce in a year. Simultaneously, all of teff producers sold their products on cash basis.

\section{Producers price setting strategy}

According to the survey result, price of the product was set by market $69.7 \%$, through negotiation and market $25.4 \%$. The remaining 2.5 and $1.6 \%$ of farmer respondents reported that the selling price of their product was set by themselves, traders and market price of that time respectively. The selling strategy of the respondent farmers was open to any buyer.

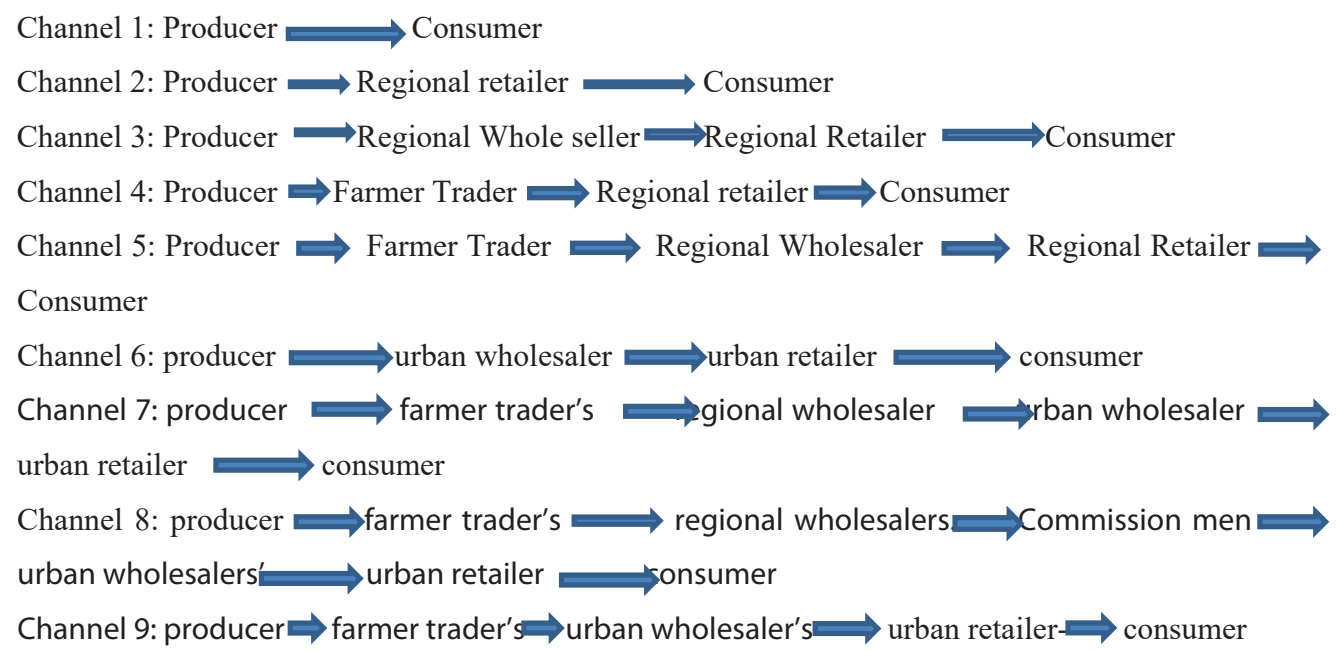




\section{Traders' market}

Place to sell: According to the result of survey, all teff traders purchased teff from farmers at the market place.

\section{Selling and buying strategy}

Based on the data from sample trader's survey, about $64.8 \%$ and $28.9 \%$ of respondents reported that buying price was set by the negotiation with supplier for market price of that day and the remaining $5.3 \%$ set by negotiation with other traders. On other hand, the survey result revealed that about $84.2 \%$ of traders responded that selling price was set by market. While the rest of $15.8 \%$ of the respondents said that selling price was set by negotiation with buyer and the market respectively. According to the assessment $5.3 \%$ and $50 \%$ of traders attracted their suppliers by Gave better price relate to other and offering credit service when they need respectively. Similarly, $44.7 \%$ of traders used a combination of offering credit service when they needed and fair scaling approaches to attract their suppliers.

\section{Market performance}

Marketing performance of teff markets were analyzed by considering associated costs, returns and market margins by taking into consideration the associated market costs for key marketing channels. Based on production costs, marketing costs and purchasing prices of the major market participants along the channels, margins at farmer, farmer traders, wholesalers, regional and urban retailer's levels were estimated and analyzed. The methods employed for analysis of performance in this study were channel comparison, profit share and marketing margin.

\section{Production Cost, Marketing costs and benefit shares of actors in teff marketing channel}

Though teff producers received different prices as sold to regional whole sellers, regional retailer, urban wholesalers and consumer, the average price was taken on analysis of benefit share of the actors (Table 3). Accordingly for the producers, ploughing, draft power, sowing and weeding cost had got the biggest percentage share of cost of production $(21.68 \%)$ and followed by land rent cost and harvesting, threshing and container cost which were $(21.62 \%)$ and $(19.93 \%)$ respectively Tables 4,5.

In a way of passing product from one actor to another, the actors improved the product quality by sorting, cleaning and creating time utility as well as incur some costs. Compared to producers $(96.24 \%)$, traders (farmer trader $(0.67 \%)$,regional wholesalers $(1.44 \%)$, regional retailer $(0.31 \%)$, urban wholesalers $(1.02 \%)$, and urban retailers $(0.35 \%)$ operating expense is only $3.76 \%$ of the total cost but their share of profit margin were $18.31 \%$, $23.50 \%, 11.19 \%, 24.29 \%$, and $6.78 \%$, respectively and that of producer was $15.93 \%$. The profit share of farmer trader was $(18.71 \%)$, regional wholesalers $(22.72 \%)$ regional retailer (11.67\%), urban wholesalers $(24.55 \%)$, and urban retailers $(6.70 \%)$. selling traders took $84.85 \%$ share of margin. While producers, performing all the work of producing quality teff and bearing the associated risks, took only $15.15 \%$ share of margin.

\section{Marketing margins of teff in different channels}

By taking the average sales prices of different participants in the teff market chain (producers, farmer traders, regional wholesalers, regional retailer, urban

Table 3: Demographics and Socioeconomics Characteristics of Households.

\begin{tabular}{|c|c|}
\hline Variables & Average \\
\hline Age & 42.93 \\
\hline Family size & 5.82 \\
\hline Distance to all weather & 3.84 \\
\hline Distance to market & 3.18 \\
\hline Types of land owned & \\
\hline Rent land & 0.96 \\
\hline Share landa & 0.175 \\
Owen land & 2.09 \\
\hline Land allocated for teff & 2.19 \\
\hline
\end{tabular}

Source: Own survey result (2018)

Table 4: Average production cost/quintal (birr) of teff producers in 2017/18.

\begin{tabular}{|l|c|c|}
\hline \multicolumn{1}{|c|}{ Input name } & Cost/qu & $\%$ \\
\hline Fertilizes (DAP+Urea) per quintal & 275 & 15.68 \\
Herbicides in liter per quintal & 7 & 0.41 \\
Insecticides in liter per quintal & 18 & 1.03 \\
Improved seed of teff per quintala & 98 & 5.59 \\
Labor force per quintal & & \\
$\checkmark \quad$ Ploughing, draft power sowing and Wedding & 371 & 21.68 \\
$\checkmark$ Harvesting , threshing and Container(Sack) & 344 & 19.93 \\
Transporting per quintal & 31 & 1.77 \\
land rent per quintal & 346 & 21.62 \\
Other cost (food \&drink) & 263 & 12.29 \\
Total production cost & 1753 & 100.00 \\
\hline
\end{tabular}

Source: Own survey result (2018)

Table 5: Average teff marketing costs and benefits of actors per quintals.

\begin{tabular}{|c|c|c|c|c|c|c|}
\hline Marketing cost in channel & Produce & $\begin{array}{l}\text { Farme } \\
\text { Trader }\end{array}$ & $\begin{array}{l}\text { Regiona } \\
\text { w.seller }\end{array}$ & $\begin{array}{l}\text { Regional } \\
\text { retailer }\end{array}$ & $\begin{array}{l}\text { Urban } \\
\text { W.selle }\end{array}$ & $\begin{array}{l}\text { Urba } \\
\text { retail }\end{array}$ \\
\hline Purchasing price & 00 & 1898 & 2013 & 2168 & 2119 & 2332 \\
\hline Production cost & 1753 & .00 & 00 & 00 & 00 & 00 \\
\hline Marketing cost & & & & & & \\
\hline $\begin{array}{l}\text { Storage loss and storage } \\
\text { cost Sorting, remixing and }\end{array}$ & & & & & & \\
\hline fill in the sacks & 4.15 & 1.01 & .56 & - & 1.2 & 3.25 \\
\hline Loading-Unloading & 0.50 & 1.20 & 2.12 & 3 & 2.17 & 0.25 \\
\hline Transport & 6.00 & 7.00 & 15.00 & - & 8.30 & 0.25 \\
\hline Information cost & .20 & .54 & .70 & 0.5 & .95 & 0.75 \\
\hline Electricity cost & - & -- & -- & 0.57 & --- & 0.5 \\
\hline Tax fee & -- & -- & .35 & 0.92 & 0.37 & 0.75 \\
\hline License fee & -- & -- & .62 & 0.42 & 0.25 & 0.47 \\
\hline Commission fee & -- & - & 5.00 & -- & 5.00 & --- \\
\hline Personal travel \& other & 5.00 & 2.61 & 2.0 & 0.25 & 0.5 & 0.25 \\
\hline Subtotal mrkting cost & 15.85 & 12.36 & 26.38 & 5.66 & 18.74 & 6.47 \\
\hline Total cost (pro + mkt) & 1768.85 & 12.36 & 26.38 & 5.66 & 18.74 & 6.47 \\
\hline Total cost $(\%)$ & 96.24 & 0.67 & 1.44 & 0.31 & 1.02 & 0.35 \\
\hline Sale price & 1894 & 2060 & 2221 & 2267 & 2334 & 2392 \\
\hline Market margin & 141 & 162 & 208 & 99 & 215 & 60 \\
\hline$\%$ share of margin & 15.93 & 18.31 & 23.50 & 11.19 & 24.29 & 6.78 \\
\hline Gross Profit & 125.15 & 149.64 & 181.62 & 93.34 & 196.26 & 53.53 \\
\hline$\%$ share of profit & 15.65 & 18.71 & 22.72 & 11.67 & 24.55 & 6.70 \\
\hline
\end{tabular}

Source: Own survey results (2018) 
wholesalers and urban retailers) the marketing margins of teff was calculated as follows Table 6 .

GMMp, GMMft, GMMrws, GMMrr, GMMuws and GMMur are gross marketing margins of producers, farmer trader, regional whole seller, regional retailer, urban whole seller and urban retailers respectively (Table 7).

The survey results showed that, the total gross marketing margin (TGMM) was highest in Channel VIII and IX and was 20.91 and $20.98 \%$ respectively (Table 7). From all actors, producers have got highest GMM in channel I when sell direct to consumer but this channel conveys limited amount of teff marketed. Again the second largest producers GMM when producer sell to retailer in channel II. However, rural retailers in channel III and V had got the lowest GMM which was accounted for 1.42 percent each.

\section{Analysis of econometric results}

Factors Affecting Marketed Supply of Teff to market: Multiple linear regression models were employed to identify the factors. Based on the regression results, the coefficient of determination $\mathrm{R}^{2}$ was 0.6504 indicating that a combination of independent variables in the regression model explained $65.04 \%$ of the variation in the dependent variable with the remaining $34.96 \%$ for uncontrollable factors in the regression model Table 8.

Total land allocated for teff: As expected the total land holding of farmers was significantly and positively influences teff market supply at $1 \%$ significant level. This indicated that

Table 6: Average price of teff at different market levels, \% share from consumer price and gross profit in 2017/18.

\begin{tabular}{|c|c|c|c|c|}
$\begin{array}{c}\text { Marketing } \\
\text { channel } \\
\text { participant }\end{array}$ & $\begin{array}{c}\text { Selling price/ } \\
\text { qu }\end{array}$ & $\begin{array}{c}\text { \% share of } \\
\text { GMM }\end{array}$ & $\begin{array}{c}\text { Gross profit } \\
\text { birr/qt }\end{array}$ & $\begin{array}{c}\text { \% share of } \\
\text { profit }\end{array}$ \\
\hline $\begin{array}{c}\text { Producers } \\
\text { Farmer traders }\end{array}$ & 1894 & 15.93 & 125.15 & 15.65 \\
Regional & 2060 & 18.31 & 149.64 & 18.71 \\
wholesale & 2221 & 23.50 & 181.62 & 22.72 \\
Regional & 2267 & 11.19 & 93.34 & 11.67 \\
retailers & 2334 & 24.29 & 196.26 & 24.55 \\
Urban & 2392 & 6.78 & 53.53 & 6.70 \\
wholesalers & & & & \\
\hline
\end{tabular}

Urban retailers

Source: Own survey result 2018

Table 7: Marketing margins of teff in different channels.

\begin{tabular}{|c|c|c|c|c|c|c|c|c|c|}
\hline $\begin{array}{c}\text { Market margin } \\
(\%)\end{array}$ & I & II & III & IV & v & VI & VII & VIII & IX \\
\hline TGMM & 00 & 12.31 & 16.96 & 19.85 & 18.30 & 18.66 & 20.38 & 20.91 & 20.98 \\
\hline GMMp & 100 & 87.69 & 83.04 & 80.15 & 81.7 & 81.34 & 79.62 & 79.09 & 79.02 \\
\hline GMMft & --- & -- & ---- & 10.16 & 8.61 & ---- & 8.33 & 8.33 & 7.85 \\
\hline GMMrw & --- & --- & 15.54 & 8.27 & 8.27 & --- & 4.96 & 5.17 & --- \\
\hline GMMrr & --- & 12.31 & 1.42 & 8.14 & 1.42 & ---- & --- & ---- & ---- \\
\hline GMMuw & --- & --- & ---- & --- & --- & 11.79 & 4.76 & 4.25 & 10.30 \\
\hline $\begin{array}{l}\text { GMMur } \\
\text { Gmmcom }\end{array}$ & $\begin{array}{l}--- \\
---\end{array}$ & --- & --- & --- & ---- & $\begin{array}{l}6.87 \\
----\end{array}$ & $\begin{array}{c}2.83 \\
---\end{array}$ & $\begin{array}{l}2.83 \\
0.33\end{array}$ & $\begin{array}{l}2.83 \\
-----\end{array}$ \\
\hline
\end{tabular}

Source: Own survey result (2018)
Table 8: Determinants of amount of teff supply to the market by producers.

\begin{tabular}{|c|c|c|c|c|}
\hline Variables & Coef. & Robust Std. Err. & $\mathbf{T}$ & $P>|t|$ \\
\hline Age of household head (AGE) & -.2520362 & 1091669 & -2.31 & 0.023 \\
\hline Number of Oxen (NOX) & 1.563016 & .7120841 & 2.19 & 0.030 \\
\hline Education level (EDUHHH) & 1.324538 & .796024 & 1.66 & 0.099 \\
\hline Family size (FMSZ) & -.3710262 & .5823387 & -0.64 & 0.525 \\
\hline Sex of household head (SEX) & -2.405324 & 2.576976 & -0.93 & 0.353 \\
\hline Income from non-farm activity & .0000447 & .0000633 & 0.71 & 0.481 \\
\hline Frequency of extension contact & -.2235822 & .4193454 & -0.53 & 0.595 \\
\hline Amount of credit used for teff & .0009319 & .0004529 & 2.06 & 0.042 \\
\hline Distance from road & -.9448672 & .4918895 & -1.92 & 0.057 \\
\hline lag Price of teff & 7.879225 & 2.42725 & 3.25 & 0.002 \\
\hline Own transportation facilities & -1.065889 & 1.746525 & -0.61 & 0.543 \\
\hline Total land allo teff in $\mathrm{Ha}$ & 7.859287 & 2.000736 & 3.93 & 0.000 \\
\hline _cons & -5.647146 & 8.752618 & -0.65 & 0.520 \\
\hline $\begin{array}{l}\text { Number of observation } \\
\qquad \begin{array}{c}\mathrm{F}(13,108) \\
\text { Prob }>\mathrm{F} \\
\text { R-squared } \\
\text { Root MSE }\end{array}\end{array}$ & & & & $\begin{array}{c}122 \\
9.19 \\
0.0000 \\
0.6504 \\
10.902\end{array}$ \\
\hline
\end{tabular}

Note: Dependent variable was amount teff supplied to the market Source: Own

Survey result 2018

the larger hectare of the land size that households had more land allocated for teff production and more would be the volume of teff marketed. The regression coefficient showed that an increase in land holding of household by one hectare increases the teff market supply by 7.85 quintal keeping all other factors held constant. This result was in agreement with the finding of Jaji, et al. [9] implies that on average, increase in the farmers' farm size by one hectare resulted in increase the quantity of pineapples supplied to market holding other things remains constant.

Education level of HHH: Education showed positive effect on teff quantity sold with significance level at $10 \%$. On average, if teff producer education level increased by one, the amount of teff supplied to the market increases by 1.32 quintal if other thing remains constant. The result further indicated that, education has improved the producing household ability to acquire new idea in relation to market information and improved production, which in turn enhanced productivity and thereby increased market supply of teff. This was in line with Addisu [10].

Amount of credit used for teff: The amount of Credit that farmers used for teff production significantly and positively influenced the teff market supply of farmers. As the amount credit used for teff production increased by one birr, the quantity of teff supplied to market increased by 0.093 kilograms, keeping all other factors held constant. This could be explained by the fact that credit is an important institutional service to finance poor farmers for input purchase. Similar results were by Jaji, et al. [9] who found increased in household head's access to credit and increased the pineapple market supply.

Distance from home to all-weather road: The distances of farmer's home from the all-weather road was significantly 
and negatively affect the teff supply to market. The results also show that farness of households settlement from all-weather road translates to reduction in volume of teff sold. One $\mathrm{km}$ increase in distance to all-weather road decreases the volume of teff output sold by about 0.94 quintal, when other factors are remained constant. In line to this, Mebrahatom [11], found that distance from homestead to all weather roads decrease the quantity of teff sold.

Age of household head: inverse of expected age of the household head significantly and negatively influenced teff market supply. An increase in the age of household head by one year decreased the teff market supply by $0.28 q u i n t a l$, keeping other things constant. Getahun, et al. [12], showed that household's tendency to participate in banana marketing decreases as farmer gets older and older.

Number of Oxen: As expected Ownership of oxen also significantly and positively affected the teff market supply. An increase in ownership of an ox had also strong positive response for increasing volume of teff production and then quantity of teff supply to market. The result of survey also showed that the quantity of teff supplied to market increased by 1.56 quintal from owning one more ox, keeping other things constant. This was in agreement with previous studies conducted by, Berhanu and Moti [13] on Commercialization of smallholders of teff.

Lagged price of Teff in the market: The coefficient of the price of teff which showed a positive relation to the quantity of teff sold or supplied to the market and highly significance at $1 \%$ level. The positive and significant relationship between the variables indicated that as the price of teff at market rose, the quantity of teff sold also rose, therefore an increase the quantity of teff sold per household per year was observed. The coefficient of the variable also confirmed that a unit price increase in the teff market directed to the household an increase yearly teff sales by 7.88 quintals, keeping other factors constant. Jaji, et al. [9] also obtain similar results on the market supply of pineapple in Malaysia.

\section{Determinants of teff producers' market outlets choice}

The Wald test $\left(\chi^{2}(53)=192.35, p=0.000\right)$ was highly significant at the $1 \%$ level, which indicated that the subset of coefficients of the model was jointly significant and that the explanatory power of the factors included in the model was satisfactory. Furthermore, results of likelihood ratio test in the model ( $\left.\operatorname{LR} \chi^{2}(6)=36.2808, p>\chi^{2}=0.0000\right)$ was statistically significant at $1 \%$ level, indicating that the independence of the disturbance terms (independence of market outlets choice) was rejected and there were significant joint correlations for two estimated coefficients across the equations in the models. The likelihood ratio test of the null hypothesis of independence between the market outlets decision $\left(\rho_{21}=\rho_{31}=\rho_{41}=\rho_{32}=\rho_{42}=\rho_{43}\right.$ $=0$ ) was significant at $1 \%$.

Separately considered, the $\rho$ values ( $\rho$ ij) indicated the degree of correlation between each pair of dependent variables. The $\rho_{21}$ (correlation between the choice for wholesaler and farmer traders outlet) and $\rho_{32}$ (correlation between the choice for retailer and wholesalers outlet) were negatively interdependent and significant at the $1 \%$ probability level indicating a competitive relationship of wholesaler outlet with farmer traders outlet and retailer outlet while $\rho_{43}$ (correlation between choice of consumer and retailer outlet) were positive and statistically significant at $10 \%$ level of significance indicated complementarity relationships between retailer and consumer outlet. This showed that in teff marketing producers used farmer trader's outlets as substitute for wholesaler outlets, and wholesaler outlets as substitute for retailer outlets in Tole district. The simulation results also indicate that the probability that teff producers choose wholesaler, farmer trader, retailer, and consumer market outlet were $69.57 \%$, $65.67 \%, 45.08 \%$ and $49.18 \%$ respectively Table 9.

Family Size (Fmlys): Family size was positively and significantly associated with selling teff to wholesalers and consumer at $10 \%$ significance level. As the family size increased by one person the probability of choice of wholesale and consumer outlet choice increased by $11.2 \%$ and $9.5 \%$ respectively. This may implied that large household size was an indicator of labour availability which enables farmers to produce more teff and sell to wholesaler outlets and also deliver it to the final consumer. Similar results was reported by Fikru, et al. (2017) who found that family size was positively and significantly influences the choice of wholesale market than other market.

Sex of Households (SHH) sex of the house hold head was positively and significantly associated with use of wholesaler's outlet at less than $1 \%$ significance level and negatively associated with the consumer market outlet choice at $5 \%$ significance level. It was also interesting to note that male head producers were more likely to deliver teff to wholesale outlet than female head households. Being a male household increase the probability of wholesale market outlet choice by $12.73 \%$ and being a female increase the probability of rural consumer market outlet choice by $8.16 \%$. Findings from other studies for Fischer and Qaim [14] determined factors that affect group membership in Kenya and also showed that female farmers were more likely to join a marketing group than male farmers, thus would most likely sell to a marketing group or cooperative.

\begin{tabular}{llllrr}
\multicolumn{2}{c}{ Education } & \multicolumn{2}{c}{ level } & of & \multicolumn{2}{c}{ households } & (Edu): \\
Education & level & of & households & had & negative \\
significant & effect & at & less than & $10 \%$ & probability
\end{tabular}
level on choosing of retailer outlet. The negative relationship between education level and selling to retailer outlet could be explained by thefact that being educated enhances adoption of new technology to boost their productivity of the production. The result showed that, if the educational level of the household was increased by one, the probability of retailer choice decrease by $16 \%$. The study conducted by Chala. and Chalchisa [15] found that literacy decreases of the probability in choosing the retailer channel for vegetables marketing and increases in choosing wholesaler market channel.

Access to market information (Aceinf): Access to market information was also positively and significantly associated with the likelihood of choosing retailer outlets and negatively 
Table 9: Determinants of teff producers market outlet choice.

\begin{tabular}{|c|c|c|c|c|c|c|c|c|c|c|c|c|}
\hline \multirow{2}{*}{ Variable } & \multicolumn{3}{|c|}{ Wholesalers } & \multicolumn{3}{|c|}{ Retailers } & \multicolumn{3}{|c|}{ Farmer traders } & \multicolumn{3}{|c|}{ Consumers } \\
\hline & Coef & RSE & \multirow{3}{*}{$\begin{array}{l}P \\
.000\end{array}$} & Coef & RSE & \multirow{2}{*}{ P } & Coef & RSE & & Coef & RSE & \multirow{3}{*}{$\begin{array}{c}\mathrm{p} \\
.016 \\
447\end{array}$} \\
\hline Sex HH & .127 & .354 & & -.213 & .342 & & .045 & .338 & & -.816 & .339 & \\
\hline Age $\mathrm{HH}$ & -.042 & .012 & & -.031 & .013 & 021 & .035 & .014 & $\begin{array}{l}.894 \\
.012\end{array}$ & .010 & .014 & \\
\hline Edu & .182 & .115 & .114 & -.323 & .133 & .016 & .012 & .119 & \multirow{2}{*}{.918} & -.054 & .117 & .642 \\
\hline Fmlys & .112 & .060 & .060 & -.034 & .069 & .591 & .043 & .056 & & .095 & .056 & .093 \\
\hline Tollteff & .509 & .241 & .035 & -.022 & .189 & .905 & -.093 & .155 & $\begin{array}{l}.454 \\
.551\end{array}$ & -.342 & .218 & .117 \\
\hline Ox & -.056 & .044 & .201 & -.010 & .047 & .713 & -.015 & .050 & & .056 & .046 & .222 \\
\hline Tqusol & -.015 & .014 & .262 & .003 & .016 & .850 & -.005 & .013 & .696 & .024 & .016 & .140 \\
\hline Frexco & .136 & .058 & .022 & -.009 & .070 & 894 & .061 & .183 & .738 & -.040 & .192 & .831 \\
\hline Accre & -.262 & .298 & .379 & -.380 & .122 & .209 & -.313 & .277 & .258 & .348 & .279 & .214 \\
\hline Aceinf & -.488 & .243 & .045 & .599 & .323 & .064 & .012 & .335 & .971 & -.015 & .016 & .354 \\
\hline Dsmr & -.109 & .105 & .184 & .072 & .122 & .556 & -.040 & .096 & $.6 / 6$ & -.006 & .094 & $\begin{array}{r}945 \\
389\end{array}$ \\
\hline Dsro & .068 & .083 & $\begin{array}{l}.412 \\
748\end{array}$ & -.019 & .100 & .049 & .141 & .074 & .050 & -.071 & .082 & $\begin{array}{l}.309 \\
353\end{array}$ \\
\hline Offar & -.022 & .070 & 578 & .128 & .077 & 156 & .014 & .069 & 032 & -.065 & -.070 & 571 \\
\hline Cons & -.385 & .693 & & 1.711 & .825 & & -1.68 & .788 & & .409 & .723 & \\
\hline & & & & & & timated correlat & tion ma & & & & & \\
\hline & & & $Y_{1}$ & & & $Y_{2}$ & & $\mathrm{Y}_{3}$ & & & $Y_{4}$ & \\
\hline$Y_{1}$ & & & 1.0000 & & & & & & & & & \\
\hline$Y_{2}$ & & & $676^{\star \star \star *}($. & & & 1.0000 & & & & & & \\
\hline$Y_{3}$ & & & ) $.003(.1 \varepsilon$ & & & $0.449 * \star \star(.153)$ & & 1.0000 & & & & \\
\hline $\mathrm{Y}_{4}$ & & & $.124(.15$ & & & $-0.165(.152)$ & & $0.075^{\star}(.151)$ & & & 000 & \\
\hline Likelihood ra & tof $Y_{21}$ & $=Y_{41}=$ & $=Y_{42}=Y$ & & & & & & & & & \\
\hline $\operatorname{chi} 2(6)=36$ & Prob > & $=0.000$ & & & & & & & & & & \\
\hline $\begin{array}{l}\star, * \star \text { and } * \star \star \\
\text { own survey }\end{array}$ & $\begin{array}{l}\text { evel of } \\
(2018)\end{array}$ & ficance & 0,5 and & specti & $\mathrm{RSE}$ is & obust standard & error, & ner traders, $Y_{2}=V$ & ers, $Y_{3}=$ & ailer an & Consu & Sout \\
\hline
\end{tabular}

significantly associated with the choice of wholesaler's outlet at $10 \%$ significance level. The result showed that as the farmers access to market information the probability of choosing the wholesalers market decreased by $48.8 \%$ and increased the probability of choice of retailer by $59.9 \%$. The findings of Kassa, et al. [16] confirmed that market information has a positive and significant effect on retailer and consumer channel choice decision of milk producers.

Land allocated for teff (tollteff): Finally, as expected, those farmers who allocated more land for teff production positively and significantly associated with choice of wholesalers outlet at $10 \%$, significance level. Increase of land allocated for teff by one hectares increase the probability of producer choice wholesale market outlet by $50.9 \%$. similar results was observed by Getachew and Nuppenau (2009) who found that large land allocated for banana positively and significantly affects the proportion sold through wholesale market outlets.

Distance to all weather roads: was found to have a significant and positive effect in the decision of choosing farmer traders outlet. The assumption was that the closer a household farm or house to all weather road, the more would be the transportation facilities access and less transport cost. As the distance from all-weather road increase by one kilometer the probability of farmer choice farmer trader's market outlet increase by $14.1 \%$. This result confirmed the finding of Shewaye [17] that distance to all weather roads was found to have a significant and positive effect in the decision of farmers in choosing rural assemblers haricot bean market outlet.

Age of respondents (Age): The variable was positively and significantly related to the use of farmer trader's market channel at $1 \%$ significant level and negatively associated to the wholesale and retail market choice outlet. As the age of teff producer increase, the probability of farmer's choice the farmer trader's market outlet is increase by $3.5 \%$ whereas there was a decrease probability to choice wholesalers and retailers outlet by $4.2 \%$ and $3.1 \%$ respectively.

Income from of/non-farm activities: Contrary to prior expectation, availability of off/nonfarm income has positive and significant relation with the choice retailer outlet at $5 \%$ probability level. From the study, producers with availability of off/non-farm income had capacity to transport their product alternatives outlets. Similar study conducted by Addisu [10] confirmed that farmers who have access to off/non-farm income had less possibility to choose rural collector outlet compared to those without access to off/nonfarm income.

Frequency of extension contact: Number of extension contact had positive and significant influence with wholesaler outlet choice decision at 5\% significance level. Those who were visited more by extension agent were more likely to deliver teff via wholesaler outlets than households less visited by extension agent. The result showed that as the extension contact of farmers increased by one the probability of choice the wholesale market increased by $13.6 \%$. Sultan [18-22] frequency of extension contact positively and significantly affected the accessibility of wholesales market outlet choices as compared with assembler market outlet choices of wheat producers $[23,24]$.

\section{Conclusion}

Market chain analysis of the study area revealed that, the main actors in the chain were producers, farmer traders, urban wholesalers, urban retailer, regional wholesalers, regional 
retailers and commission men. The four firm's concentration ratio (CR4) indicated that the four largest traders handled $59.44 \%$ of the total volume of purchased teff. Suggesting that, the structure of the teff market in the study area was somewhat strong oligopoly feature.

Multiple linear regression models were run to identify determinant of volume of teff marketed. Age of household head, education of house hold head, number of oxen farmers owned, amount of credit that farmers used for teff production, distance from road, total land farmers owned and lag price teff was found significant. The multivariate probit model applied in this study was specifically intended to investigate factors influencing the teff farmers in choosing marketing outlets. The study also showed that the teff producer farmers in the study area made their choice of market outlets for their produce based education level of households, sex of households, age of house hold, family size, access of off/non-farm income, frequency of extension contact, land allocated for teff and distance to all weather roads.

\section{Recommendations}

The government should establish cooperatives among teff producing areas to minimize the existing strong oligopoly market structure. Strengthening the existing credit institutions and simplify way of provision for farmers in the area will help farmers to boost their supply. The concerned authority should be able to increase the awareness of households about the importance of education and about the school age at which their children should join the school. Government intervention should be needed for the expansion of schools in which the communities would be equally benefited.

Expanding equal accessibility of infrastructures such as road and transportation facilities to reducing transaction costs needs government intervention to promote the effective marketing of teff product supply through all outlets. Providing appropriate market information is another essential component for teff producer to choose appropriate market outlet. Therefore, putting in place and strengthening reliable institutions for conveying timely and adequate market information for teff producers was very essential. Improve extension system which focused on market extension and linkage of farmers with markets is necessary to ensure a reliable market outlet for producers of the study area.

\section{References}

1. Birara E (2017) Teff Production And Marketing In Ethiopia Bahir Dar University Ethiopia. Radix International Journal Of Research In Social Science 6.

2. CSA (Central, Statistical Agency (2017) Agricultural sample survey report on Area and production of major Crops (private peasant holdings, meher season 2016 / 2017; Addis Ababa Ethiopia, the FDRE statistical bulletin I.

3. Engida E, Minten B, Tamru S, Kuma T (2013) Ethiopia"s Value Chains on the Move: The Case of Tef Addis Ababa, Ethiopia. Link: https://bit.ly/3qzNOSu

4. Emana B (2010) Market Assessment and Value Chain Analysis in Benishangul Gumuz Regional State, Ethiopia; Final Report, SID-Consult-Support Integrated Development. Addis ababa. Link: https://bit.ly/3o7k0jd
5. Turaa EG, Goshub D, Demisiec T, Kenead T (2016) Analysis of Teff Value Chain in Bacho and Dawo Districts of South West Shewa, Ethiopia. Journal of Agricultural Economics and Development 5: 020-032. Link: https://bit.ly/3sOzY5m

6. Bekele AH, Melaku CT, Asha LD (2017) Determinants ofsmallholder farmers in teff market supply in ambo district, west shoa zone of oromia, Ethiopia. International Journal of Advanced Research in Management and Social Sciences 6. Link: https://bit.ly/3pe6gVu

7. Twoar (2017) Tole Woreda Office of Agriculture and Rural Development Bantu.

8. Yamane T (1967) Statistics: An Introductory Analysis,2nd Ed., New York: Harper and Row. Link: https://bit.ly/3c7NVWp

9. Mendoza G (1995) A Primer on marketing channels and margins. Lyme Rimer Publishers Inc,USA.

10. Pomeroy RS, Trinidad AC (1995) Industrial Organization and Market Analysis: Prices,Products, and People: Analyzing Agricultural Markets in Developing Countries. Lynne Reinner Publishers, Boulder. London.

11. Jaji K, Man N, Nawi NM (2018) Factors affecting pineapple market supply in Johor, Malaysia Department of Agribusiness and Bioresource Economics, Faculty of Agriculture, Universiti Putra Malaysia (UPM), 43400 Serdang, Selangor, Malaysia. International Food Research Journal 25: 366-375.

12. Addisu H (2016) Value Chain Analysis Of Vegetables: The Case Of Ejere District, West Shoa Zone, Oromia National Regional State Of Ethiopia. A Thesis Submitted To School Of Agricultural Economics And Agribusiness, Postgraduate Program Directorate. Haramaya University, Haramaya.

13. Medhane M (2014) Determinants Of Commercialization Of Teff And Its Factor Productivity Outcome: The Case Of Tahtay Qoraro Woreda, Northwest Zone of Tigray Regional State, Ethiopia M.Sc. Thesis.

14. Getahun KE (2017) Determinants of Smallholder Market Participation Among Banana Growers In Bench Maji Zone, Southwest Ethiopia International Journa Of Agricultural Policy And Research 5: 169-177. Link: https://bit.ly/362DzTK

15. Gebremedhin B, Jaleta M (2010) Commercialization of smallholders: is marketparticipation enough?. AAAE third conference/AEASA 48th conference, September 19-23, Cape Town, South Africa. No. 96159. African Association of Agricultural Economists (AAAE) andAgricultural Economics Associa. Link: https://bit.ly/2YgjGEB

16. Fischer EA (2011) Linking Smallholders to Markets: Determinants and Impacts of Farmer Collective Action in Kenya. World Development. 40: 1255-1268. Link: https://bit.ly/3sGZSrT

17. Hussen CH, Fana C (2017) Determinants of Market outlet Choice for Major Vegetables Crop: Evidence from Smallholder Farmers' of Ambo and TokeKutaye Districts, West Shewa, Ethiopia. International Journal of Agricultural Marketing 4: 161-169. Link: https://bit.ly/3qIVxCl

18. Kassa T, Haji J, Tegene B (2017) Determinants of honey producer market outlet choice in Chena District, southern Ethiopia: a multivariate probit regression analysis. Agricultural and Food Economics. Link: https://bit.ly/2Y1ygzF

19. Shewaye A (2016) Econometric Analysis of Factors Affecting Haricot Bean Market Outlet Choices in Misrak Badawacho District, Ethiopia. International Journal of Research Studies in Agricultural Sciences (IJRSAS) 2: 6-12. Link: https://bit.ly/39ST023

20. Sultan UM (2016) Analysis Of Wheat Value Chain: The Case Of Sinana District,Bale Zone, Oromia Region, Ethiopia Msc Thesis Haramaya University. Link: https://bit.ly/3qLKgkP

21. Federal DR (2014) Population Projection of Ethiopia for All Regions at Woreda Level from 2014-2017

22. Sikawa Y, Mugisha J (2011) Factors influencing south-western uganda dairy 
farmers' choice of the milk marketing channel: a case study of kirihura district south western uganda 1. Link: https://bit.ly/3qMMgJT

23. Asefa S, Mulugeta W, Hadji J (2016) Determinants of Farmers' Preference to Coffee Market Outlet in Jimma Zone: Developing Country Studies 6. Link: https://bit.ly/3iF55M3
24. Vavilov NI (1992) Origin and Geography of Cultivated Plants. Articles and Lectures of Vavilov 1924-1940, first collected and published in book form in Russian in 1987 (Cambridge: Cambridge University Press).
Discover a bigger Impact and Visibility of your article publication with Peertechz Publications

\section{Highlights}

* Signatory publisher of ORCID

* Signatory Publisher of DORA (San Francisco Declaration on Research Assessment)

* Articles archived in worlds' renowned service providers such as Portico, CNKI, AGRIS, TDNet, Base (Bielefeld University Library), CrossRef, Scilit, J-Gate etc.

* Journals indexed in ICMJE, SHERPA/ROMEO, Google Scholar etc.

* OAI-PMH (Open Archives Initiative Protocol for Metadata Harvesting)

* Dedicated Editorial Board for every journal

* Accurate and rapid peer-review process

* Increased citations of published articles through promotions

* Reduced timeline for article publication

Submit your articles and experience a new surge in publication services

(https://www.peertechz.com/submission).

Peertechz journals wishes everlasting success in your every endeavours.

Copyright: @ 2021 Dibaba TL. This is an open-access article distributed under the terms of the Creative Commons Attribution License, which permits unrestricted use, distribution, and reproduction in any medium, provided the original author and source are credited. 